\title{
THE NATURAL HISTORY OF CORDIERITE AND ITS ASSOCIATES.
}

\author{
By I. J. H TEALI, M.A., E.R.S., F.G.S.
}

(Prisidential Adiriss, ditiered fibruary 3rd, 189g.)

DRING the last thirty years an extraordinary outburst of
petrological activity has taken place in consequence of
the application of precise mineralogical methods to the study of rocks. The petrologist, and through him the geologist, owes therefore, an enormous debt of gratitude to the mineralugist; but while acknowledging this debt, I desire to point out that the benefits, due to the more intimate union between geology and mineralogy which has thus been established, are not wholly onesided. If petrology owes much to mineralogy, it has in its turn conferred benefits upon the latter science. Striking evidence of this is furnished by the important work on the mineralogy of France and her Colonies by Professor Lacroix, who is not only a mineralogist but a distinguished petrographer and geologist. 'Ihis book, unlike the older mineralogies, is not a mere catalogue of the crystallographic, chemical, and optical characters of museum specimens, but a series of monographs in which the different minerals are treated from all points of view, and in which due importance is attached to their modes of occurrence and origin. This welcome change is, it seems to me, largely due to the influence of petrology upon mineralogy.

I.et me try to illustrate the advantage of studying minerals from what may perhaps be termed the natural history point of view, by giving some account of a small group which has attracted my attention at intervals during the last few years. I refer to the "faithful companions"--corundum, spinelle, sillimanite, and cordierite.

Corundum is crystallised alumina $\left(\mathrm{Al}_{2} \mathrm{O}_{3}\right)$ and is therefore the simplest of the four in composition. Its crystals belong to the hexagonal or rhombohedral system, and vary in habit and colour according to their mode of occurrence. Many beautiful gems such as ruby and sapphire are merely varieties of corundum.

True spinelle is an aluminate of magnesia $\left(\mathrm{MgO}_{3} \mathrm{Al}_{2} \mathrm{O}_{3}\right)$, and, like all the members of the group, crystallises in the cubic system in the form of octahedra. Between true spinelle and magnetite $\left(\mathrm{FeO}, \mathrm{Fe}_{2} \mathrm{O}_{3}\right)$ there are many intermediate varieties in which ferrous iron takes the place of magnesium and ferric iron that of aluminium in almost any proportion; so that the general formula for the group, excluding the chrome-spinelles, to which I MAY, I8g9.? 
do not propose to refer, may be written $(\mathrm{MgFe}) \mathrm{O},\left(\mathrm{Al}_{2} \mathrm{Fe}_{3}\right) \mathrm{O}_{3}$ These intermediate forms are usually green in colour, the depth of tint increasing to opacity as the amount of iron increases. As it is impossible to distinguish different varieties, such as pleonaste and hercynite, under the microscope they will simply be referred to as green spinelles.

Sillimanite is the simple silicate of alumina $\left(\mathrm{Al}_{2} \mathrm{O}_{3}, \mathrm{SiO}_{2}\right)$. It crystallises in the rhombic system as long slender prisms, which are often so thin as to appear like needles or hairs under the microscope.

Cordierite is a silicate of alumina and magnesia with some iron replacing the magnesium $\left(2 \mathrm{MgO}, 2 \mathrm{Al}_{2} \mathrm{O}_{3}, 5 \mathrm{SiO}_{2}\right)$. It may be said to bear the same relation to spinelle that sillimanite does to corundum. Thus sillimanite is corundum plus silica; and cordierite is spinelle plus silica. Cordierite crystallises in the orthorhombic system, and is found under two conditions. In the gneisses and contact-rocks it occurs, as a rule, in irregular colourless grains which are not pleochroic in thin sections, except a round minute inclusions of zircon. In this form it is often crowded with needles of sillimanite, and not infrequently contains also small and more or less rounded scales of biotite.

In volcanic rocks it often occurs as six-sided prisms, cross sections of which break up into sectors in polarised light. There is thus a marked difference in habit between the cordierite of the gneisses and contact-rocks, on the one hand, and that of the volcanic locks on the other. The cordierite of the volcanic rocks is, moreover, often pleochroic.

Now these minerals, usually in combinations of two or more, occur under the most diverse geological conditions. They are found :

I. As the constituents of foliated crystaline rocks belonging to the so-called Archæan formation.

2. As the products of contact-metamorphism round plutonic masses.

3. As the constituents of inclusions in $(a)$ plutonic igneous rocks, $(b)$ dykes, and $(c)$ volcanic rocks, including both lavas and agglomerates.

4. As the direct products of the crystallisation of natural silicate-magmas.

5. As the direct products of the crystallisation of artificial silicate-magmas.

It is impossible within the limits of this address to do more than refer to one or two typical examples of each of these modes of occurrence.

Cordierite-gneisses are found in many parts of the world in association with other foliated crystalline rocks, and also not infrequently in the neighbourhood of granites containing cordierite into which they are said to pass. Bodenmais, in 
Bavaria, is one of the best known localities. Here cordierite occurs in connection with sillimanite, biotite, quartz, iron-ores, garnet, and sometimes also with orthoclase and oligoclase. The sillimanite may be either crowded together in clots or bundles, or may occur as inclusions in the cordierite, and sometimes also in the other minerals. The cordierite is irregular in form and colourless, with yellow pleochroic halos round zircons ; but it does not show the division into sectors or the pleochroism which are so characteristic of the cordierite of volcanic rocks.

Similar rocks occur in the granulite region of Saxony, at Tvedstrand in Norway, in the Central Plateau of France, and many other localities.

Various views have been expressed as to their origin. Some are content simply to refer them to the Archæan system; others regard them as due to the contact or thermo-dynamic metamorphism of ordinary argillaceous sediments; and others as rocks of mixed origin, that is as rocks containing both igneous and sedimentary material.

The last view, although it is certainly not applicable to all cases, deserves more than a passing notice, for where cordieritebearing rocks occur as contact products they usually belong to the inner zones and sometimes give distinct evidence of the intimate intermixture of granitic and sedimentary material. If mixed rocks of this kind were foliated by deformation they would unquestionably produce cordierite-gneisses.

Cordierite-bearing rocks, often containing sillimanite and spinelle, have been recognised at many points in the Eastern Highlands in the counties of Aberdeen, Banff, and Forfar. A general account of these rocks was given in the Explanation to Sheet 75. I will quote a description of a specimen from the top. of the Buck of Cabrach collected by Mr. Hinxman.

"This is a massive, dark, bluish rock spangled with small flakes of white mica. It possesses a somewhat spotted appearance in consequence of the presence of individuals or aggregates of cordierite. The colourless constituents, cordierite, andalusite, white mica, microcline and quartz, make up the main mass of the rock. The dark minerals are magnetite and biotite, but the latter is very feebly represented. Cordierite, andalusite and white mica usually contain numerous inclusions of magnetite and quartz and thus show the micropoikilitic structure which is so common in contact minerals. All the massive cordierite-bearing rocks show a characteristic bluish-grey colour, but they vary in composition. A specimen from the railway cutting south-east of Little Arnage is of considerable interest as throwing light on a subject I have already referred to. It is evidently a compound rock due to the superposition of igneous upon metamorphic material. The igneous portion is represented by more or less idiomorphic oligoclase, biotite, orthoclase and quartz; the 
metamorphic portion by cordierite, quartz, biotite, sillimanite, iron ores and a green spinelle. The rock into which the granitic magma was intruded is now represented by somewhat ill-defined shreds, patches, and streaks in a paste of igneous origin."

Since the Explanation of Sheet 75 was published other specimens of the same type of rock have been sent up for examination by Mr. Barrow and Mr. Kynaston. Mr. Barrow's specimens were collected in the Glen Muich area, and one of these, composed of cordierite, sillimanite, quartz, biotite, iron-ores, green spinelle, and probably a little felspar, was analysed. It contained, as might naturally be inferred from its mineralogical composition, a very high percentage $(324)$ of alumina. $\mathrm{Mr}$. Barrow looks upon the rock as the result of the general thermometamorphism which has affected the Frastern Highlands and which was associated with the intrusion of the earlier granitic material. Mr. Kynaston's specimens come from the neighbourbood of the Ben Cruachan granite and are regarded by him as normal contact-rocks due to this mass of granite. They are medium grained, dark, bluish grey, fairly massive rocks, composed of cordierite, andalusite, alkali-felspar, oligoclase, biotite, pyrite, and a green spinelle. Quartz is sometimes, but not always, present.

In describing rocks of this type from the Eastern Highlands, I have more than once called attention to the fact that corundum might naturally be expected to occur in them, but that it could not be detected in the thin sections. The presence of a colourless grain which might possibly be corundum in one of the slides of a specimen from the neighbourhood of Ben Cruachan led me to examine the rock in another way. The coarse powder was placed in hydrofluoric acid and allowed to digest for several days, with the result that corundum was found in the residue together with pyrite, spinelle, and a few crystals of rutile that had escaped notice in the slide.

The corundum in this rock occurs in crystals and more or less irregular grains. The crystals are combinations of the hexagonal prism, the primitive rhombohedron, and the basal plane. They are sometimes flat and sometimes prismatic. The flat forms in which the prism is feebly developed are frequently stepped on the basal plain owing to the repeated alternations of this face with the faces of a rhombohedron. This habit is not unfrequent in corundums. It may be seen in some of the Burma rubies and is a marked feature of the Montana "sapphires."

A very interesting case of the occurrence of all four minerals in rocks produced by contact-metamorphism has been described by Salomon ${ }^{(18)}$ * The important mountain mass of which Monte Adamello ( $\mathrm{I}, 68 \mathrm{I} \mathrm{ft}$.) forms the culminating point is situated in the southern portion of the Eastern Alps. It consists of a nucleus

*The small figures refer to the list of papers quoted at the end of the Addres 
of tonalite or quartz-diorite surrounded by a girdle of sedimentary rocks of different ages, many of which show the effects of contact-metamorphism.

The rocks with which we are more immediately concerned form part of a zone following the western margin of the intrusive mass, along which they have been traced for a distance of fourteen kilometres. They represent portions of the older, more or less metamorphosed sedimentary rocks of the Alps which have been still further metamorphosed by the tonalite. The most characteristic rock of the inner zone consists of fifty, or very often of sixty or seventy per cent. of cordierite associated with various other minerals, including biotite, andalusite, sillimanite, quartz, titaniferous iron-ore, and, in certain special cases, plagioclase, orthoclase, garnet, spinelle, and corundum. There is often a most intimate association of the cordierite-bearing contact-rock and the igneous mass, and inclusions of the former occur in the latter.

So much for contact-rocks. We pass on now to consider other modes of occurrence. Inclusions containing two or more of the minerals in question, sometimes all four together, are found in plutonic masses, dykes, lavas, and agglomerates. They occur, for example, in the tonalite, to which I have just referred, in the kersantite dyke of Michaelstein in the $\mathrm{Hart}^{(\theta)}$, in andesitic lavas of the Eifel ${ }^{(19)}$, the Siebengebirge $e^{(3)}$, and the province of Almeria, in the south-east of Spain ${ }^{(14)}$; and, finally, in the ejected blocks of the Laacher See and of Asama Yama in Japan $^{(5)}$. By piecing together the evidence furnished by different localities we seem to be able to trace these inclusions from their birthplace in the infernal regions to their final resting-place on the earth's surface. The subterranean magmas act powerfully on their containing walls, and transform highly argillaceous sediments into crystalline rocks composed of cordierite, sillimanite, biotite, quartz, and sometimes spinelle and corundum. The rocks of the inner contact-zone become shattered, and the igneous magma insinuates itself between the cracks, or may even permeate the mass. Portions of the metamorphic rock float off into the molten material and travel with it through dykes and other channels to the surface, where they form either inclusions in a lava or ejected blocks in an agglomerate, according to the conditions of the eruption. This, no doubt, is the explanation of the presence of inclusions containing the minerals in question in some cases, but it by no means supplies a full explanation of all the facts. Many of the inclusions, especially those found in dykes, lavas, and agglomerates, resemble fragments of cordierite-gneisses rather than normal contact rocks; others contain the minerals in a form different from that in which they occur either in the gneisses or the contact-rocks. To illustrate these points we must consider one or two typical cases. 
The kersantite-dyke, near Michaelstein ${ }^{(6)}$, is intrusıve in clay-slate with subordinate layers of limestone, quartzite and kiesel-schiefer. The rock, which is dark-grey, almost black in colour, is composed of numerous phenocrysts of biotite and a few of felspar, set in a compact matrix. Under the microscope enstatite and cordierite may be recognised, and the latter mineral occurs in such a way as to prove that it must have crystallised from the magma. It forms sharply defined six-sided prisms, cross sections break up in polarised light into sectors-often six-and opposite sectors extinguish simultaneously. These features are not those of the cordierite of the gneisses or contactrocks, and they undoubtedly prove that the mineral has been formed where we now see it. But the occurrence of authigenic cordierite is by no means the only peculiar feature of this remarkable dyke. It is crowded with minerals which are obviously foreign to the rock, including felspar, garnet, sillimanite, cyanite, quartz, biotite, rutile, spinelle, apatite, corundum, staurolite, hypersthene, calcite, magnetite, anatase, and titaniferous iron-mica. They occur either singly or in aggregates. Scarcely a slide or specimen can be found without one or more of them, and the aggregates vary from microscopic dimensions up to the size of a walnut, or even larger. In some cases half the rock is made up of foreign constituents.

Before dealing with the significance of these facts, let us consider one or two other cases of an allied nature. The hornblende-andesites of Bochsberg and Rengersfeld in the Eifel, described by Vogelsang ${ }^{(19)}$, are not homogeneous in character. They contain masses which sometimes have the aspect of included fragments and sometimes that of streaks merely differing in character from the rest of the rock. The minerals of which these aggregates are composed are cordierite, andalusite, sillimanite, telspar, biotite, pleonaste, corundum, rutile, quartz, garnet, zircon, and magnetite-that is much the same association as that found in the foreign substances in the Michaelstein dyke. The aggregates, which are formed of somewhat variable combinations of the minerals I have mentioned, are sometimes easily separable from the matrix, at other times firmly welded to it. They vary in size from microscopic dimensions up to masses $6 \mathrm{cms}$. in diameter, or in the case of the streaks $12 \mathrm{cms}$. in length.

A very common type consists of a fine-grained, grey rock, essentially composed of cordierite, andalusite, sillimanite, and plagioclase. The cordierite is irregular in form, intensely pleochroic, and often twinned. It contains grains of rutile, needles of sillimanite, and inclusions of glass.

Andalusite is next to cordierite the most abundant constituent. Sillimanite occurs in fibrous aggregates between the other constituents, and also as inclusions within them. Biotite is 
not uncommon, and is often found in association with a brown amorphous substance which appears to have been formed by the partial melting of the mineral. Pleonaste or green spinelle occurs in the inclusion, and is also found abundantly in wellformed octahedra in the andesite immediately surrounding the inclusion.

There can be no doubt that these inclusions have been derived either from the crystalline schists or from a contact-zone. Vogelsang, who has studied them in great detail, inclines to the former view. The occurrence of spinelle in the andesite immediately surrounding the inclusions is of special interest. This, like the cordierite in the kersantite of Michaelstein, undoubtedly owes its origin to the chemical change in the magma consequent on the solution of a certain amount of the material of the inclusions.

Another interesting case of a somewhat similar character occurs in the province of Almeria, in Spain ${ }^{(14)}$. The south-east coast of Spain, from Cabo di Gata to the neighbourhood of Carthagena, a distance of about two hundred kilometres, is bordered by a zone of volcanic rocks belonging to the upper Miocene or early Pliocene periods. They are not continuously exposed, but appear at intervais from beneath the upper Pliocene deposits.

This zone of volcanic action bears the same relation to the alpine folds of the mountains of Andalusia as do the volcanic rocks of the northern coast of Africa to the corresponding folds of the Atlas system, and as do the Tertiary volcanic rocks of Italy to those of the Apennines.

A plain of upper Pliocene rocks separates the Sierra Alhamilla, which belongs to the central zone, from the Sierra del Cabo di Gata which is formed entirely of volancic rocks. On the northern side of this plain are several small hills, one of which, Hoyazo, has a curious crater-like depression in the centre. This depression can be entered by following the course of a ravine which is about 200 yards long. The bottom of the depression is about 200 feet below the rim, which is almost circular, and about $35^{\circ}$ yards in diameter. The lower part of the wall is formed of andesite and andesitic tuffs, the upper part (6-I $3 \mathrm{ft}$.) of marine limestone containing bivalves and gasteropods. In the upper part the slope is steep, often vertical ; in the lower part, formed of the volcanic rocks, it is less steep. The limestone forms a mantle to the hill which was for a long time regarded as a typical crater of elevation. There is, however, clear evidence that the limestone was deposited on the igneous rocks, and that there has been no volcanic action since its deposition.

The volcanic rock is a mica-andesite. It contains phenocrysts of a basic plagioclase, biotite, rhombic pyroxene, and hornblende in a glassy base. But the most interesting constituent is 
cordierite. This occurs in two forms-as irregularly bounded optically uniform grains up to the size of a hazel-hut, and as sharply defined idiomorphic crystals. The former are inclusions ; the latter are crystals which have separated from the magma. In addition to the mineral inclusions there are also rock fragments varying in size from that of a head down to microscopic dimensions. These are (I) quartz blocks, (2) lumps of quartz and cordierite, and (3) fragments of cordierite-biotite-gneiss with garnet.

Osann, whose description I am quoting, points out that the extraordinary abundance of indigenous cordierite coupled with the presence of numerous inclusions of cordierite-gneiss lead to the conclusion that portions of the foreign rock have been dissolved and that a magma of exceptional composition, out of which cordierite has separated on cooling, has thus been formed. blocks.

We have now to consider the evidence furnished by ejected

The volcano of the Laacher See, like that of Vesuvius, is remarkable for the number and variety of the ejected blocks occurring in the agglomerates. They include fragments of crystalline foliated rocks, blocks mainly formed of sanidine, and fragments of trachyte; the two last being obviously connected with the magma. Of the crystalline schists, cordierite-gneisses are the most abundant. They occur in their normal condition, and also show the effects of the great heat to which they have been subjected during the eruption. Dittmar ${ }^{(3)}$ divides the cordieritebearing rocks into three classes: (I) cordierite-gneiss with sillimanite, (2) massive rocks containing newly formed felspar and cordierite, and $(3)$ spotted schists.

In rocks of the first group, which show little or no alteration by heat, the cordierite is clear, very slightly pleochroic, and contains inclusions of spinelle and corundum. In rocks which have been acted upon it is strongly pleochroic and mostly free from sillimanite. It is also surrounded by a zone of glass, and contains secondary glass-inclusions, The biotite in these rocks has often been fused to a glass out of which spinelle has separated. In still more highly altered rocks the original minerals have entirely disappeared, and newly formed cordierite is seen lying in a matrix of brown glass.

Many other cases of a similar character might be quoted, but one must suffice. A basalt occurring near Kollnitz ${ }^{(17)}$ in Carinthia, has involved fragments of an argillaceous rock and partially dissolved them. The normal basalt is composed of plagioclase, augite, olivine and magnetite, and is almost holocrystalline. The included fragments are associated with glassy streaks or schlieren, in which cordierite and spinelle have been formed. The partial solution of the fragments evidently modified the composition of the magma so that it cooled as a glass after cordierite and spinelle 
had separated out. The story is the same as that told by the ejected blocks of the Laacher See, the andesites of Hoyazo and the Eifel, and the kersantite dyke of Michaelstein. It is very interesting to note that the addition of alumina to the basaltic magma has hindered its crystallisation. This effect of alumina in preventing crystallisation is well known to glass makers.

Corundum has been recorded as occurring in many igneous rocks, and in some of these it is undoubtedly indigenous. Professor Lagorio, ${ }^{(9)}$ who was, I believe, the first to insist on the igneous origin of corundum, cites many instances, but unfortunately in several of these the mineral has certainly not crystallised out of the magma. Nevertheless, there are not a few well authenticated cases ; for example, the corundum-pegmatites and corundum-syenites of the Urals ${ }^{(13)}$ and the very remarkable corundum-syenites of Hastings County, Canada, recently discovered by the Geological Survey of the Dominion, and admirably described by $\mathrm{Mr}$. Miller. (11) In all these cases the matrix of the idiomorphic corundum is formed of alkali-felspar, sometimes associated with nepheline. Moreover, the intrusive character of the Canadian rocks is quite clear.

Then, to come nearer home, there is the interesting case described by Professor Busz. (2) The mineral occurs in a felsite, intrusive in clay slates, near South Brent. It is present in extremely minute tabular crystals $\left({ }^{\circ} \circ 2-^{\circ} \circ 3 \mathrm{~mm}\right.$.), sometimes showing hexagonal outlines, and is most abundant near the contact of the felsite with the clay slates. It is, no doubt, due, as Professor Busz states, to the fact that portions of the slates were dissolved by the felsitic magma, which became super-saturated with alumina on cooling, and thus gave rise to the formation of corundum.

Another apparently well-authenticated case, is that of the socalled Montana sapphires. The minerals were first found and worked in an auriferous glacial gravel near the head waters of the Missouri, but they were subsequently discovered by Mr. G. F. Kuntz in an igneous rock which Prof. Miers described as a vesicular mica-augite-andesite. Still later, corundum was found near Yogo Gulch, fifteen miles south of Utica, in a yellow, earthy material which could be traced across the country for a considerable distance in an east and west direction, and which evidently resulted from the alteration of an igneous dyke. In working downwards the unaltered igneous rock was reached and this has been described by Prof. Pirsson as a basic lamprophyre, consisting mainly of biotite and pyroxene. Speaking of the relation of the corundum crystals to the matrix Prof. Pirsson (15) says: "The clear-cut form of the crystals and their general distribution shows that they had crystallised out of the magma with as much certainty as the well-formed phenocrysts of felspar in a porphyry betray their origin." He explains the presence of the mineral by supposing that the original magma dissolved 
portions of the "clay shales" of the district and thus, on cooling, became supersaturated with alumina.

If Prof. Pirsson's theory be true we have here a case of the formation of corundum in a basic magma containing limemagnesia silicates. As will be seen later on there are some difficulties in the way of accepting this theory, but I am not sure that they are sufficient to destroy the force of the facts recorded by him.

We have now arrived at the last stage of our enquiry. A recently-published paper by Dr. Morosewicz, ${ }^{113 !}$ of Warsaw, gives a complete or nearly complete account of the conditions under which the four minerals (corundum, spinelle, sillimanite, and cordierite) form in igneous rocks. The researches described in this paper extended over a period of five or six years, and the results obtained are, from a petrographical point of view, some of the most interesting that have appeared during recent years. They must rank in importance with the artificial production of igneous rocks by Messrs. Fouqué and Lévy.

The experiments were made in a Siemens' furnace in a glass factory near Warsaw. In his attempts to make artificial rocks, Dr. Morosewicz accidentally produced some more or less crystalline masses extremely rich in corundum and spinelle. This led him to determine the chemical conditions under which these minerals had been formed.

$\mathrm{He}$ isolated and analysed them, and also ascertained the composition of the mass which remained after they had separated out, for they always belonged to the first period of consolidation. $\mathrm{He}$ found that the ratio of the alumina-silicate bases $\left(\mathrm{K}_{2} \mathrm{O}, \mathrm{Na}_{2} \mathrm{O}\right.$, $\mathrm{CaO}$ ) to the alumina, in what may be called the mother-liquor, was very nearly $\mathrm{I}: \mathrm{x}$. This is the ratio characteristic of the felspar group, and the fact naturally suggested the conclusion that, when alumina is present in excess of that given by this ratio, it is liable to crystallise out in the form of corundum alone, of corundum and spinelle, or of spinelle alone; the amount of spinelle being determined by the amount of magnesia present.

$\mathrm{He}$ then proceeded to verify this conclusion by dissolving alumina in artificial magmas corresponding to anorthite, nepheline, albite, orthoclase, and to mixtures of these. The results were completely in accordance with theory, except that a pure orthoclase-magma was found, to his astonishment, to possess little or no power of dissolving alumina. But this was not all. One or two additional facts of great interest revealed themselves during the progress of the research.

Alumina, in the form of bauxite, was found to be soluble in different proportions in the different magmas. Thus, in one case, two mixtures were prepared; one corresponding approximately to anorthite with two per cent. of soda, another to nepheline with one and a half per cent. of lime. 'To $2 \mathrm{z} 2 \mathrm{lbs}$. of the first, $50 \mathrm{lbs}$. of 
bauxite were added, and to the same amount of the second, 100 bs. of the same substance. In four hours the nepheline mixture melted to a homogenous mass in the hottest part of the furnace (about I,300 deg. C.), but after twenty-four hours the anorthite mixture, under the same conditions, was imperfectly fused, a considerable amount of alumina remaining undissolved. After cooling it was found that the nepheline mixture was crowded with microlites and minute crystals of corundum and nepheline, and that the anorthite mixture contained cavities in which beautiful glistening crystals of corundum were associated with unmelted grains of alumina. The nepheline mixture contained 29.5 per cent. of corundum, whilst the anorthite mixture contained only 5 per cent. Thus, under similar conditions as to temperature, alumina is six times more soluble in a nephelinemagma than in an anorthite-magma.

The experiments with the albite-magma were exceptionally interesting, for in addition to corundum, needles of sillimanite were obtained, and as these sometimes pierced the corundums it was clear that they had formed first. Now, in albite $\left(\mathrm{Na}_{2} \mathrm{O}\right.$, $\mathrm{Al}_{2} \mathrm{O}_{3}, 6 \mathrm{Si} \mathrm{O}$ ) the ratio of soda to alumina to silica is $1: 1: 6$. The formation of sillimanite might therefore be reasonably expected to occur if there were an excess of silica as well as alumina above that given by this ratio. Further experiments proved that this is the correct explanation. Sillimanite could easily be produced by making a magma in which both alumina and silica were in excess of that given by the ratio $1: \mathbf{1}: 6$.

Here then we have a clear demonstration of the conditions under which corundum and sillimanite may form in igneous magmas. Spinelie and cordierite come under the same law. Both require the presence of magnesia, and cordierite requires also an excess of silica above that necessary to form felspar with the soda, potash and lime present. Twenty-five grammes of a mixture corresponding to pure spinelle $\left(\mathrm{MgO}, \mathrm{Al}_{2} \mathrm{O}_{3}\right)$ were added to a mixture corresponding to albite. The cooled mass was found to be crowded with microlites of spinelle. Plates of corundum and prisms of sillimanite were also formed near the wall of the crucible, but not in the centre of the mass.

Cordierite was formed in a magma of andesitic character in which the ratio of the felspathic bases to alumina to silica was $x: 1 \times 25: 7$ and in which 5 per cent. of magnesia was present. The cooled mass consisted of idiomorphic crystals of cordierite, octahedra of spinelle, prisms of labradorite, and microlites of augite in a glassy base. It bore the closest resemblance to a cordierite-vitrophyrite from the Orange Free State described by Molengraaf, and to the allied rocks from the south-east of Spain to which I have already referred.

Dr. Morosewicz summarises his results as follows:

In supersaturated alumina-silicate-magmas whose general com- 
position is $\mathrm{MeO}, m \mathrm{Al}_{2} \mathrm{O}_{3}, n \mathrm{SiO}_{2}\left(\mathrm{Me}=\mathrm{K}_{2}, \mathrm{Na}_{2}, \mathrm{Ca} ; n \bar{\nu}_{2}\right)$, the whole of the excess of alumina $(n-I)$ separates out : (a) as corundum if no magnesia or ferrous iron be present, and if $n$ be $<6$; (b) as sillimanite or sillimanite and corundum if $n$ be $>6$. When the magmas are rich in magnesia the excess of alumina separates out (c) as spinelle or spinelle and corundum if $n$ be $<6$; and (d) as cordierite or cordierite and one or more of the other minerals if $n$ be $>6$.

The experiments of Dr. Morosewicz give a very complete and satisfactory account of the conditions under which corundum forms in telspathic magmas. But the mineral is found also in non-felspathic rocks, such as the dunite of North Carolina, where, according to Dr. Pratt ${ }^{(16)}$, it has crystallised out of a dunitemagma.

Now, in his experiments with basic magmas containing magnesia, Morosewicz found that silicates of magnesia were rare or absent in those masses which contained corundum. Almost the whole of the magnesia combined with alumina to form spinelle, and it was only when there was a deficiency of magnesia that corundum was produced. Moreover, in magmas with an excess of silica over that necessary to form felspar, cordierite was produced. How then can alumina crystallise out of a highly magnesian silicate-magma? Why are not spinelle and cordierite formed instead ?

I cannot answer these questions. IVill someone who has the necessary means at his disposal experiment on the solubility of bauxite in a peridotic magma? If Pratt's theory of the origin of the North Carolina corundum be correct, alumina should be soluble and should separate out as corundum.

In the preceding sketch of the natural history of corundum, spinelle, sillimanite, and cordierite, I have by no means exhausted the subject. I have merely called attention to a number of wellestablished facts which throw a considerable amount of light on the mode of origin of these interesting minerals. It is clear that they may be formed by the crystallisation of sedimentary deposits under the conditions which prevail in the deeper portions of the earth's crust, and that they may also crystallise out of molten magmas. They serve therefore as a bond of union between igneous and sedimentary rocks. The cordierite-bearing contactrocks have certainly never been in a state of igneous fusion; and yet there has been a sufficient amount of molecular freedom to admit of groupings of the same type as those occurring in molten magmas.

To what extent can these minerals be regarded as the products of normal igneous magmas? In many cases where they occur as authigenic constituents, they have undoubtedly crystallised from a magma which has been modified by the absorption of foreign material. Indeed, so frequently is this the 
case, that the very existence of normal magmas capable of forming corundum, cordierite, and sillimanite is, I think, open to question. But, however this may be, there can be no doubt that such magmas are local and exceptional.

How does this fact bear on the question of the absorption of sediments by igneous rocks? In clays, shales, and slates there is a large excess of alumina over that required to form felspar with the alkalis and lime present. Thus in a Coal Measure clay from Fifeshire recently analysed by Dr. Pollard, the molecular ratio of the alkalies and lime to alumina is $\mathrm{I}: 4.9 \mathrm{I}$; in two slates from the Ardennes, analysed by Prof. Renard, it is $1: 5.8$ and 1 : 3.5 respectively. If such rocks were absorbed by granite on an extensive scale, would not sillimanite and cordierite be far more common than they actually are? At first sight one is inclined to answer this question unhesitatingly in the affirmative; but caution is necessary, for under plutonic conditions micas may form instead of them.

Thus, I have noticed, where biotite-gneisses have been used in the construction of vitrified forts in Scotland, that the biotite is often represented by a brown glass containing beautiful little octahedra of spinelle, and Vernadsky has shown that the fusion of muscovite gives rise to the formation of sillimanite and corundum.

Now if the water in biotite be reckoned as a base along with potash the ratio of $\left(\mathrm{K}_{3}, \mathrm{H}_{2}\right) \mathrm{O}$ to $\mathrm{Al}_{2} \mathrm{O}_{3}$ is $\mathrm{I}: \mathrm{I}$ as in the felspars, but in fused biotite after the water has been driven off it is $I: 1 \cdot 3$, and the conditions necessary for the formation of spinelle exist. In fused muscovite the ratio is $I: 3$, and as there is no magnesia the conditions necessary for the formation of sillimanite and corundum exist. Thus the absence of the minerals in question from plutonic rocks cannot by itself be taken as evidence that no absorption of argillaceous sediment has taken place. Nevertheless, I think that when the distribution and quantitative relations of the micas to the other constituents are taken into consideration, there is good evidence, quite apart from the field relations, that granite masses, such as those of Cornwall, the south of Scotland, and the newer granites of the Highlands of Scotland, have not absorbed or dissolved any appreciable amount of argillaceous material. When we come to the older granites and the associated gneisses of the Highlands, which, as Mr. Barrow has shown, are so intimately connected with intense and widespread metamorphism, the case may be different. The extraordinary abundance of micas in some varieties may very possibly represent in part sedimentary material which has taken this form instead of giving rise to corundum, spinelle, sillimanite, or cordierite as it might have done if the water had escaped.

But the full discussion of this question would carry us too far, and I must conclude by expressing the hope that $I$ have succeeded 
in proving that great interest attaches to the study of minerals from all points of view, and that it is only by combining the results of geological, mineralogical, and chemical research that their natural history, in the proper sense of the term, can be made out.

\section{LITERATURE OF THE SUBJECT.}

I. Barrington Brown and Prof. Junn.-"The Rubies of Burma." Trans. Royal Soc., Lond., vol. clxxxviia, I 896, pp. I 5 I-228.

2. Busz, Prof.- " On the occurrence of Corundum, produced by Contactmetamorphism." Geol. Mag., 1896, p. 492.

3. Dittmar, Dr. Carl._-" Mikroskopische Untersuchung der aus krystallinischen Gesteinen, insbesondre aus Schiefer herrürhenden Auswürflinge, des Laacher See." Verh. d. natur. Ver. Rhein, etc., Bonn, 1887 , s. 477 .

4. Holland, T. H. " A Manual of the Geology of India." Economic Geology. 2nd edition, 1898 . Part I, Corundum.

5. HussaK, Dr. E.- "Ueber den Cordierit in Vulkanischen Auswürflingen." Sitz. d. k. Akad. d. Wiss. Wien, B. LXXXVII (1883), s. 332.

6. Koch, Max.- "Die Kersantite des Unterharzes." Gahr. d.preuss. geol. Landesanst, I 886, s. 44 .

7. LACRoTx, Prof, A.- "Les modifications endomorphes du Gabbro du Pallet (Loire Inférieure)." Compt. Rend., T. CXXVII (1898), p. 1038. "Sur la formation de Cordierite dans les roches sedimentaires fondues par les incendies des houilleres de Commentry." Compt. Rend., T. CXIII (1891), p. 1060.

9. LAGORIo. Prof, A.- "Pyrogener Korund, dessen Verbreitung und Herkunft." Zeit.f. Kryst, B. XXIV (I895), s. 285.

10. Lasalix, Prof. A, voN.-" Ueber das optische Verhalten und die Mikrostructur des Korund." Zeit.f. Kryst., B. X (I885), s. 346.

II. Miller, Willet G.-"Economic Geology of Eastern Ontario" (Corundum and other minerals). Report of the Burean of Mines, vol. vii, third part, 1898, p. 207.

12. MolengraAF, G. A. F.-Cordierit in einem Eruptivgestein aus SüdAfrica." Neues Fahrb., I 894, B. I, s. 79.

13. MOROSEWICZ, JOSEF.- "Experimentelle Untersuchungen ueber die Bildung der Minerale im Magma." Tscher. Mitth., Bd. XVIII (1898), pp. I-9o and I05-240.

If OSANN, Dr. A.- "Ueber den Cordierit-iührenden Andesite vom Hoyazo" (Cabo di Gata) Zeit. d. deut. geol. Gesell., B. XL (1888), p. 7or.

15. Pirsson, L. V.- "On the Corundum-bearing Rock from Yogo Gulch, Montana" Amer. Four. Sci, 4th Series, vol. iv (1897), p. 42 r.

I6. PRATT, J. H.-." On the origin of the Corundum associated with the Peridotites in North Carolina." Amer. Four. Sci., 4th Series, vol. vi, 1898, p. 49.

I7. ProHASKA. "Ueber den Basalt von Kollnitz im Lavantthale und dessen glasige Cordierit-führende Einschlüsse." Sitz. d.k. Akad. d. Wiss. Wien, B XCJI (1885), s. 20.

I8. Salomon, Dr. W.-"Geologische und petrographische Studien am Monte Aviolo." Zeit. d. deut. geol. Gesell., B. XLII (1890), s. 450.

I9. Vogelsang, Dr. Karl, "Beiträge zur Kenntniss der Trachyt-und Basalt-gesteine der hohen Eifel." Zeit. d. deut. geol. Gesell., B. XLII (1890), p. 25. 